\title{
ECO-PESANTREN ASSESSMENT STUDY OF ISLAMIC BOARDING SCHOOL IN
} BANDA ACEH, INDONESIA

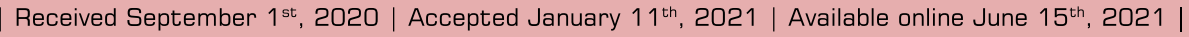
| DOI http://dx. doi. org/10.18860/jia.v6i3.7967 |

Maysarah Bakri

UIN Ar-Raniry

Banda Aceh, Indonesia

Maysarah.bakri@gmail.com

\begin{abstract}
The implementation of Eco-Pesantren is a contribution of the Islamic Architecture product towards the current global issue. Eco-Pesantren aims to produce a green Islamic boarding school, which contributes a positive effect in terms of environmental conservation and energy saving. Therefore, this research assesses the Eco-Pesantren implementation of Darul Ulum Islamic Boarding School in Banda Aceh. The research method is descriptive qualitative. The researcher collects data through in-situ observation based on the research tool. The result shows that this Islamic Boarding School is not yet categorized as an Eco-Pesantren. To implement this concept, the management should improve some aspects such as optimizing natural renewable resources, optimizing the existing green space, and optimizing waste management. This study also reveals the role of architects in implementing the Eco-building concept and determines the building performance.
\end{abstract}

KEYWORDS:

Eco-Pesantren, Islamic Boarding School, the role of an architect.

\section{INTRODUCTION}

The concept of sustainability emerges as one of the solutions for current issues. Those issues are environmental problems, such as global warming, social conflict, and economic issue, such as poverty [1]. This concept should be implemented in all sides of life holistically as the environment is in the worst situation. Related to that, Indonesia's Minister of Environment had launched the so-called Eco-Pesantren in 2011. The program is a sustainable practice that aims to produce the green Islamic Boarding School (Pesantren) and add benefits to society's social and economics. The targets are the availability of a healthy and pollution-free environment, the increase of the society's income, the availability of the job vacancy, and better social cohesion. The pesantren is believed as the proper institution to implement the Eco-Pesantren as it is an Islamic education institution which therefore should represent the Islamic values [2][3][4].

The term of Eco-Pesantren arises from the knowledge of Eco-Architecture. Eco-Architecture is a knowledge that studies the relationship of the environment, the human, and the building [5]. EcoArchitecture is one designing way that considers the ecological aspects [1], which includes considering the existing ecosystem on the site. Eco-Architecture forms and preserves the human-environment interaction. A critical concept of Eco-Architecture is the availability of coexisting conditions between humans, the other living things, and the building as the architectural prod- ucts [1]. Eco-Architecture relates to solar architecture, the bionic-natural structure, sustainable material and construction, alternative architecture, and biological architecture [6]. In other words, Eco-Architecture includes optimizing solar energy, creating green buildings, optimizing the green material, and considering the user's health. It shows that the success of this concept depends on many aspects, and it includes the human as an essential player.

Moreover, there are four principles of Ecological Sustainable Development which can be seen in table 1.

\begin{tabular}{ll}
\multicolumn{2}{l}{ Table 1. The Ecological Sustainable Development Principles } \\
[6]
\end{tabular}

The Ecological Sustainable Development Principles consist of the material aspect, the energy system, the waste management, and the biological diversity, 
which should be implemented to achieve "EcoBuilding." The whole elements affect the humanenvironment interaction that will contribute to the existing ecosystem. So, the human should act wisely to prevent the negative impact towards that ecosystem. The explanation above shows that the essence of EcoArchitecture is to reach the ideal condition in which the building as the architectural product facilitates the human need as well as the animals and the vegetation. In the equilibrium setting, the living thing-building relationship creates mutualism and supports each existence. That harmonic relationship will increase the quality of the user's life and building performance.

The practice of the Eco-Pesantren can be done through various activities such as providing the pesantren waste bank, providing the water treatment installation, providing the green activities which can be achieved by doing plantation through the vertical garden method, the hydroponic method, or the greenhouse method, improving the green lifestyle, developing the health and environment unit in the Islamic Boarding School, integrating the environment curriculum, and providing the waste and water management [3][7]. However, it needs to raise the students' awareness to do green activities [8]. It can be done through the socialization of a green lifestyle. Once the understanding arises, the student will participate voluntarily in preserving environmental activities [8].

As a religious, educational institution, the Islamic Boarding School has a basis for applying green activities. In Islam, as the Caliph, the human is ordered to maintain the equilibrium in the universe. One representation of that order is a caring and preservation activity while fulfilling the human needs [9], known as ecological spirituality [10]. Based on Islamic sustainable value, humans should perform good behavior to others, including a harmonious relationship with the environment. The ecological spirituality in Islam is strengthened by the environment preservation concept introduced by Rasulullah SAW, which is the conservation areas (hima) and the concept of land reclamation (ihya'ul mawat) [7]. It shows that as Rahmatan lil 'alamin religion, Islam focuses on human welfare and considers the environmental quality as the habitat of the living things. The religious aspect plays an essential role in promoting sustainability because it shapes the human perspective and guides the behavior towards the environment [9] [11]. To increase the awareness and foster sustainability holistically, the human should fully understand and implement this core value, especially in Islamic Boarding School as religious education school.

The implementation of Eco-Pesantren needs other agents' support and participation. A comprehensive study shows that its performance involves many aspects and supporting agents such as the students, teachers, society, and even the government [12][13]. The architect also holds a vital role in implementing the Eco-Pesantren concept. The practice of Eco-building starts from the decision-making process. In this phase, the architect ensures the green concept in the design since it will influence the building performance [14]. Eco-building is achieved through green decisionmaking, green construction [15], and green behavior during the occupation. This chain cannot be separated and supports each other to produce a green building. It is much easier to apply to the new building while faces many challenges in the existing building.

The green concept must be integrated into an architectural design method to establish a solid basis for a green design [14]. However, the passive approach has to be prioritized in implementing it. A guidelines structure in integrating a green concept in an architectural design method is divided into four phases which are "Program and Data Collection (consideration made towards Site and Climate, Urban Context and Condition, Adapting the program to the site, Internal consumption, and needs); Feasibility Study (consists of Building Orientation, Building Envelope, Building Form and Landscape); Preliminary Design (including some aspects such as Structure, Internal Layout, Opening Elements, Shading Elements, Natural Ventilation, Additional Energy-Efficient strategies, Heating, and Cooling Solutions); and in the Detailed Strategies Phase (such as Material Selection, Thermal Insulation Materials, Construction Details, Water Fixtures, Building Management, and Low Consumption Devices Selection)" [14]. This guideline gives a clear description to the architect on implementing the green concept on the design method that varies from a passive approach to an active approach.

The architect should realize that any design decision would impact many things such as the environment, the social, and the economic aspect. Therefore, the architect has to consider and apply the green concept in the design process. Besides the current requirement, it also shows the architect's responsibility in terms of environmental preservation. The architect should take part in this action because this sector contributes significant impacts on the environment [14]. The implementation of Eco-building principles shifts the building plan from the linear plan towards a close circulation plan. It creates a self-sufficient building [16] that significantly minimizes the impacts on the environment that signs as good building performance.

In 2011, Aceh was chosen to be the pioneer in the EcoPesantren program, which involved several Islamic Boarding schools. Unfortunately, its success was not heard. This program is very promising, especially for the improvement of environmental quality. To encourage this concept, there is a need to assess the possibility of the Eco-Pesantren implementation toward the Islamic Boarding Schools in Aceh. The assessment is done to investigate the potencies of the Islamic Boarding School so that the Eco-Pesantren can be implemented optimally.

One of the potential Islamic Boarding Schools is Darul Ulum Islamic Boarding School, Banda Aceh. It is located in an urban setting and has 4 Hectares of land areas. The optimum site planning will create a better microclimate which contributes to the site and the surrounding. It will reduce the pollution level and in- 
crease the amount of open space on the urban scale. Therefore, the surrounded area will benefit from the existence of green open space in this Islamic Boarding School. The hypothesis raises that the benefit will spread wider if this Islamic Boarding School implements the other Eco-Pesantren principles such as optimizing the renewable resource or providing waste management. Based on that explanation, the object of this research is Darul Ulum Islamic Boarding School, Banda Aceh. The study aims to find the potencies of Darul Ulum Islamic Boarding School, Banda Aceh, which can be developed further as the basis of the EcoPesantren. As the first assessment in Darul Ulum Islamic Boarding School, the research focuses only on the physical aspects of the building and the site.

\section{METHODS}

The method of this research is qualitative descriptive. The qualitative method is suitable for the topic of this research because it is in a natural setting. This will guarantee the research result. However, this method requires the role of the researcher for interpreting the data [17]. In this study, the scope of the research is the physical objects of the building and the site. The limitation is based on the research instrument adapted from the Ecological Architecture Principles [6]. So, the observed objects are the material of the building, the energy system, the waste management, and the biological diversity on the site. As this Islamic Boarding School is a multi-mass building, the research focuses on three buildings: the classroom, the male, and the female dormitory, because the students the most frequently use these three buildings.

The research object is Darul Ulum Islamic Boarding School located in Banda Aceh, Aceh, Indonesia. The coordinate of this Islamic Boarding School is $5^{\circ} 33^{\prime} 38.4$ "N 95¹9'47.3 "E.

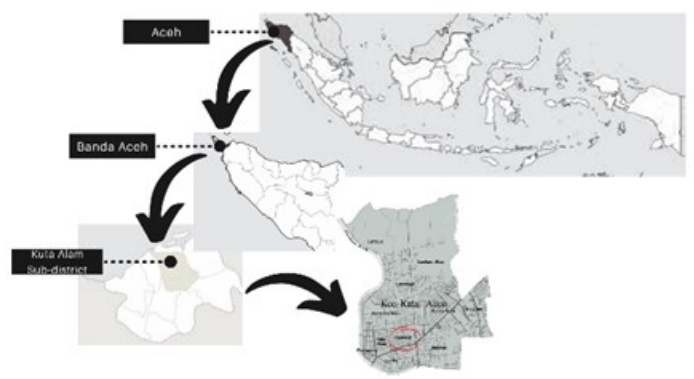

Figure 1. The Key plan of Darul Ulum Islamic Boarding School (Source: the author)

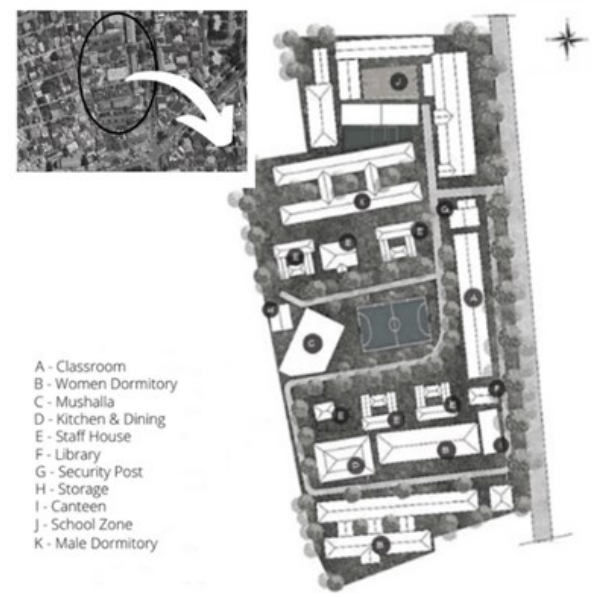

Figure 2. The masterplan of Darul Ulum Islamic Boarding School (Source: the author)

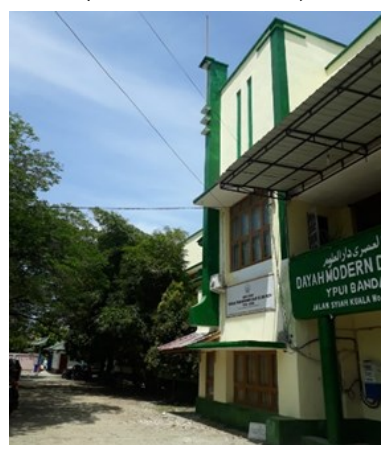

Figure 3. Darul Ulum Islamic Boarding School (Source: the author)

Table 2. The Research Instrument [6 - adapted]

\begin{tabular}{|c|c|c|c|}
\hline $\begin{array}{l}\text { The } \\
\text { Princi- } \\
\text { ples }\end{array}$ & The Application & $\begin{array}{l}\text { Availa- } \\
\text { bility }\end{array}$ & $\begin{array}{l}\text { Quality } \\
\text { of Im- } \\
\text { plement } \\
\text { ation }\end{array}$ \\
\hline Material & $\begin{array}{l}\text { Minimizing the material } \\
\text { resource } \\
\text { Using the local material } \\
\text { Using renewable material } \\
\text { Using the reusable material }\end{array}$ & & \\
\hline $\begin{array}{l}\text { System } \\
\text { of Ener- }\end{array}$ & $\begin{array}{l}\text { Prioritizing the material } \\
\text { efficiency }\end{array}$ & & \\
\hline gy & $\begin{array}{l}\text { Using solar energy } \\
\text { Using wind energy } \\
\text { Using water energy } \\
\text { Using the biogas energy } \\
\text { Prioritizing the energy } \\
\text { efficiency } \\
\text { Using natural lighting } \\
\text { Using the natural cooling } \\
\text { system } \\
\text { Using self-water resource }\end{array}$ & & \\
\hline $\begin{array}{l}\text { The } \\
\text { waste } \\
\text { manage- } \\
\text { ment }\end{array}$ & $\begin{array}{l}\text { Using the leftover/ organic } \\
\text { material as the fertilizer } \\
\text { Reduce } \\
\text { Reuse } \\
\text { Recycle }\end{array}$ & & \\
\hline $\begin{array}{l}\text { The } \\
\text { biologi- } \\
\text { cal diver- } \\
\text { sity }\end{array}$ & $\begin{array}{l}\text { Providing the green open } \\
\text { space } \\
\text { Increasing the variety and } \\
\text { the quantity of vegetation } \\
\text { Providing the habitat for } \\
\text { the animals }\end{array}$ & & \\
\hline
\end{tabular}


The researcher collects data through an in-situ observation. It is done based on the research instrument that can be seen in table 2 . The observation started at $2.00 \mathrm{pm}$ until $6.00 \mathrm{pm}$ because the activities in this Islamic Boarding School happens during that time.

Based on the observation results, the pesantren is categorized into; the Eco-Pesantren and the not Eco-Pesantren. The Eco-Pesantren has a good quality of ecological principles implementation and vice versa. The researcher also tries to find the reason behind the success or unsuccessful of Eco-Pesantren in this research object, especially the architect's role. As stated previously, the architect is responsible for four phases of the architectural design method. Moreover, the analysis will also be made toward the potency of the existing building related to the implementation of Eco-Pesantren [18].

\section{DISCUSSION}

THE ROLE OF ARCHITECT IN IMPLEMENTING AN ECOBUILDING CONCEPT

Based on the observation, Darul Ulum Islamic Boarding School implements some Eco-Pesantren concepts. The implementations are using the nearby material, providing the green open space, increasing the variety and the quantity of the vegetation, and providing the habitat for the animals.

The building uses material from the area of Banda Aceh and Aceh Besar. The use of the material nearby reduces the ecological footprint. However, the building does not use rattan or bamboo, which is well known as green material [19]. It mainly uses common materials such as brick, iron, and concrete. Meanwhile, wood is also used on the roof structure and as the finishing material. Besides, other finishing materials are applied in the building, such as ceramic, glass, and iron sheeting. The wood, the iron, and the iron sheeting are reusable materials. The use of wood in the building is one positive step because the material can be decomposed by nature, need less energy, and minimize the pollution that fits the ecological material's criteria. However, it is not the primary material in the building. Other materials consume more energy, although it has the potential to be reused. In the design process, material selection is in the phase of detailed strategies. This building does not consider the use of green material. It results in more energy consumption in terms of material choices.

Furthermore, the building does not apply renewable energy in the building operation. The energy system is mostly fossil energy. The building also does not optimize the sunlight as natural lighting. Some of the classes and some dormitory rooms still need to turn on the lamp in the daytime. It is because of the furniture arrangement in the room that hinders the sunlight. It consumes much energy considering the number of rooms that use artificial lighting. Moreover, the building does not optimize the wind as the natural cooling system. Some of it uses Air Conditioner, while others use a fan. The existence of vegetation on the site and the existence of the cross-ventilation system have not provided thermal comfort in the rooms.

One of the energy problems is building orientation. The site plan (figure 4) shows that the classroom (building A) faces the west. Amongst the other buildings, the classroom is the only west-oriented building in this Islamic school complex. As the learning activities happen in the afternoon time, the student feels uncomfortable in the building. The west wall absorbs the sunlight and transmits it into the classroom. Therefore, the observation found that the student turned the fan on during the study time in the class. There is some vegetation in front of it. It decreases the temperature of the classroom on the first floor. However, it creates another problem for the first-floor classroom. The student needs to turn on the lamp in the daytime because the vegetation hides the sunlight.

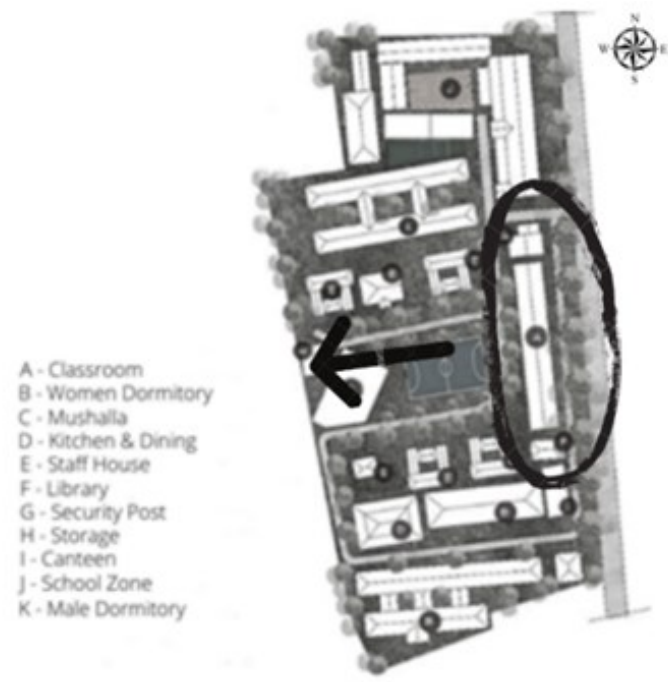

Figure 4. The classroom orientation (Source: the author)

This building orientation also impacts the cooling system in the building. Based on the climate in Banda Aceh, the building opening is suggested on the north and the south of the building to avoid the heat of sunlight. Moreover, the west wind usually brings along the dust and high speed. By putting the opening on the north and the south, the wind is cleaner and fresh. In this research object, the classroom opening mainly on the west side of the building causes heat in the interior because of its orientation. The classroom has a crossventilation system, but it does not work optimally. The upper ventilation is a small window type that the student requires to open. As it is in a high position, it is not accessible for the student to keep it opened. The lower ventilation clogs because of the waste (figure 5). Those two ventilations are part of the cross-ventilation system in the building. Regrettably, it does not maintain good causes of the uncomfortable thermal condition. Furthermore, the classroom is a single-loaded corridor type (figure 6). This type allows optimum natural lighting and cooling system. Unfortunately, it is not achieved because the building is west-oriented that causes uncomfortable thermal conditions. 


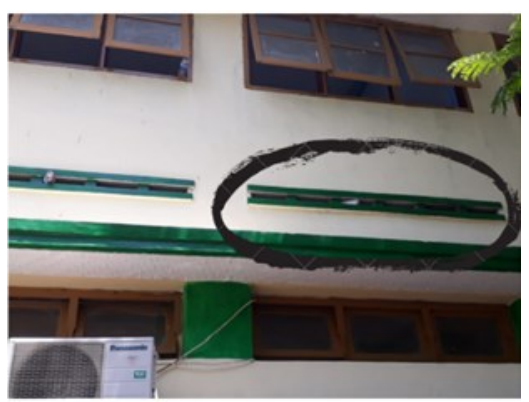

Figure 5. The lower ventilation in the classroom (Source: the author)

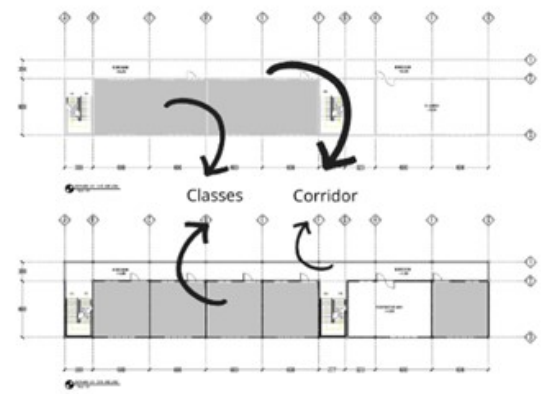

Figure 6. The classroom floor plan (Source: the author)

Meanwhile, the male dormitory and female dormitory are oriented to the south and the north. The $\mathrm{H}$ shape male dormitory (building $K$ ) faces to the south while the women dormitory (building $B$ ) is northoriented (figure 7). This orientation allows the building receives constant natural light throughout the day. The issue occurs in the west room (figure 8 ). The wall of this west room absorbs the sun's heat and transfers it into the interior. It increases the room temperature and affects thermal comfort at night. In the architectural design methods, it is suggested not to design a west sleeping room as the sun heat will be transmitted to the room in the tropical region, which causes un comfortable thermal temperature. However, the architect can plant the trees west of the site or apply a second skin to anticipate the heat transfer. In this research object, there are some shady trees in the west of the room. The existence of these trees decreases the temperature in that area, particularly in the surrounding of the west room.

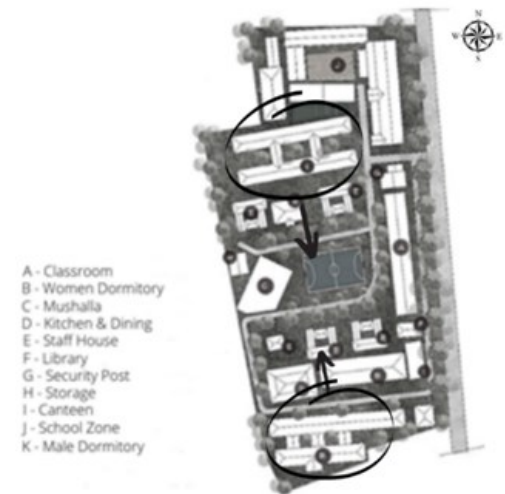

Figure 7. The dormitory is north-south orientated (Source: the author)
Both dormitories apply a single loaded corridor and provide a courtyard that optimizes the natural ventilation system and the natural lighting. Theoretically, the dormitories' orientation allows optimum sunlight penetration. However, these dormitories consume more energy since the inhabitant turns the light on during the day. It happens because of an unorganized interior. The furniture arrangement hinders natural lighting. The bunk beds place near the window. As it is high, it deters the sunlight causes the student need to turns on the lamp in the daytime. It is unknown whether the architect sets this interior or the inhabitant arranges it by themselves.
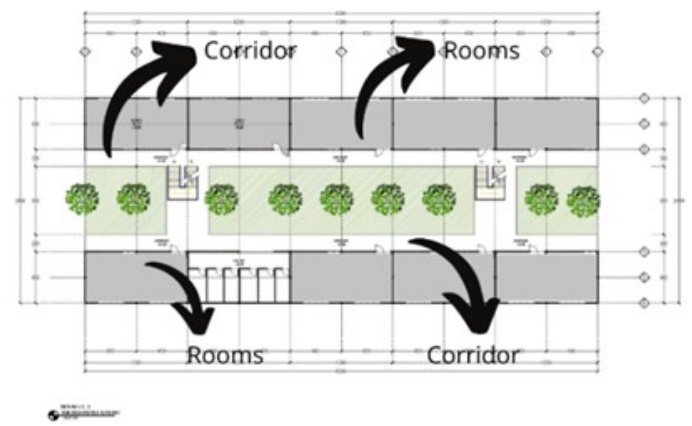

Figure 8. The dormitory floor plan (Source: the author)

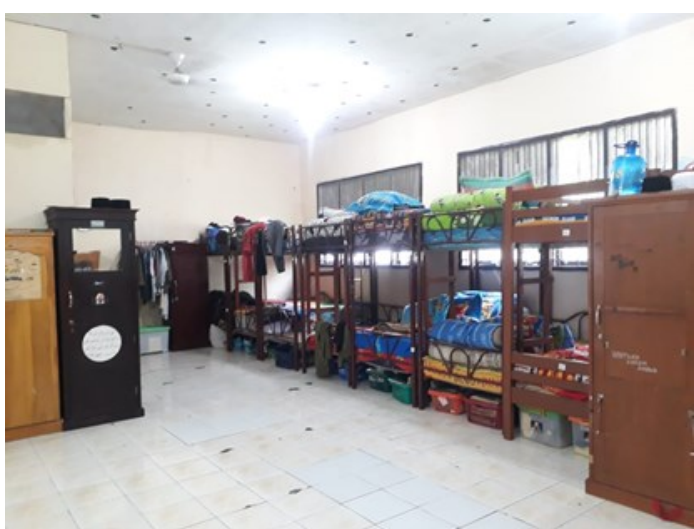

Figure 9. Furniture setting in the dormitory hinders the natural lighting (Source: the author)

Despite the problems stated above, the building form has adjusted to Indonesia's climate. As designed in a tropical region, the building applies a gable roof to solve the wind problem and avoids roof leaks. All buildings implement the thin building concept to accelerate the heat release. However, the building does not provide thermal comfort for the user. It is mainly because of the building orientation and the cross-ventilation system, which also affects the energy consumption in the building.

From the waste management aspect, the building has thoroughly organized the waste. The plastic waste is put in a particular container. There is an instruction to separate dry and wet waste. Unfortunately, the implementation is not optimum. It is related to user behavior, which is not used to separate the waste. Moreover, existing waste management has not been 
seen as an attempt to reduce and reuse trash. The organic waste has not been treated to be fertilizer. However, there is an attempt to recycle, although it is just for a particular event. Reduce, reuse, and recycle (3R) concept has not been a part of the user's daily life. Therefore, there is a need to implement this concept in user daily activities.

In terms of biological diversity, the research object applies all the implementation of this application. There is some vegetation on the site, such as Bambusa vulgaris, Tamarindus indica, Casuarinaceae, Roystonea regi, Mangifera indica, Polyalthia longifolia, and Syzygium oleana. Although it has not yet reached $60 \%$ of the site, the existence of the green space on the site reduces the temperature. Some of the vegetation create the shading effect which cooling the surrounding. However, some of the vegetation should be trimmed so that it does not hinder the sunlight. Furthermore, there is a chance to optimize the quality of the existing green space to be used by the public.

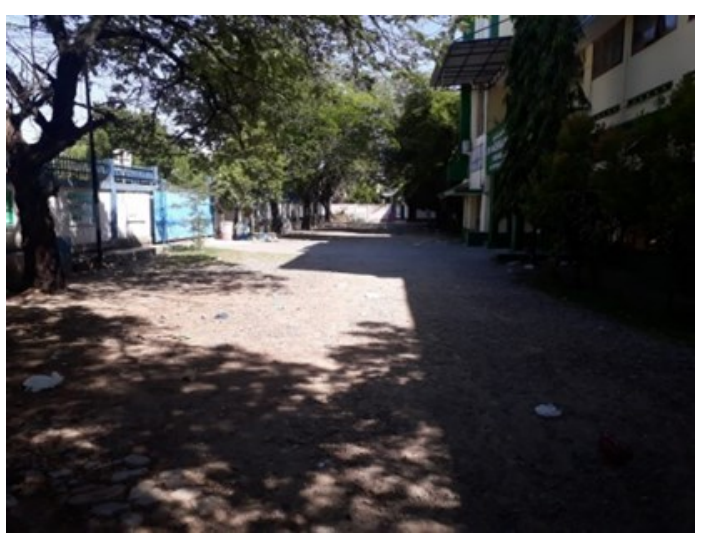

Figure 10. Front yard situation (Source: the author)

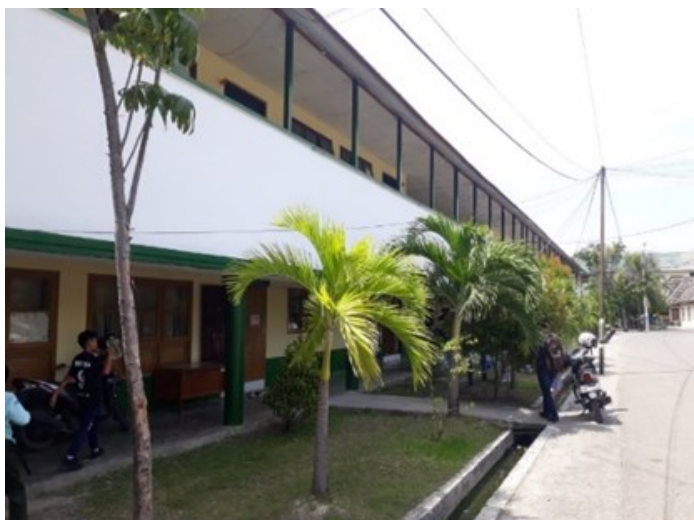

Figure 11. The green space in front of the school building (Source: the author)

The result of the research also reveals the role of architects in the implementation of Eco-building. In this case study, the role of the architect is unknown. There is no information about who the architect is or what the building concept is. As the building concept is unknown, the implementation of an Eco-building in this research object is very minimal. This research object shows an example of how an architect determines building performance. It is not categorized yet as an Eco-building, it needs to do more tasks to achieve an optimum Eco-building implementation. It can be avoided if the architect has considered the green concept in the decision-making process. The building will implement a green concept optimally, and the building will achieve optimum performance. From the four phases of architectural design methods, the phase of feasibility study and phase of preliminary design is the more decisive phase than the other phase. The design decisions in these phases include building orientation, building envelope, building form, structure, internal layout, opening elements, shading elements, and natural ventilation. The description above has shown that the unresponsive building orientation, the unorganized interior layout, the opening elements, and the natural ventilation system affect the performance of the building, such as thermal comfort and energy consumption. If the architect considers and implements the green concept from the early stage, this could be prevented, and better building performance will be achieved.

\section{(ACTIVE-PASSIVE) ARCHITECTURAL APPROACHES}

Moreover, the existing building can optimize the potencies so that the Eco-Pesantren can be implemented. Physically, the potencies of Darul Ulum Islamic Boarding School are the availability of natural renewable resources such as the sun, the wind, and the rainwater; the availability of the green open space which planted various vegetation; and the availability of simple waste treatment.

The renewable resources available on the site are the sun, rainwater, and wind. All of these resources can be optimized as alternative energy resources to decrease the consumption of fossil energy. The use of renewable energy is one of the Ecological Sustainable Development Principles. Among the three of them, solar energy is the most powerful alternative energy resource. Using the solar cell, the sunlight will be absorbed and converted to be the electrical energy used in the building. Previous research has shown that solar panels can reduce the consumption of conventional energy [20][21]. Although it has not been able to replace conventional energy, solar panel use contributes to environmental improvement significantly. The solar cell can be installed on the roof, the list plank over the stack, or the façade [22]. The simple installation device should encourage the architect to optimize the solar energy in the building. It is even supported by the fact that Indonesia gets stable sunlight throughout the year.

Furthermore, the rainwater can be reused for the building and the site. The harvesting rainwater can be used for kitchen needs or watering the plants. Currently, the building has no rainwater harvesting system. The use of rainwater in simple installation can reduce the consumption of conventional water up to $54.92 \%$ [23]. Also, the rainwater harvesting system can decrease the runoff by up to $71.53 \%$ [23]. Considering 
the rainwater intensity in Banda Aceh and its benefits, the rainwater harvesting system can be developed further.

Meanwhile, the wind can be optimized as a natural cooling system. Currently, the building has implemented a cross-ventilation system. However, the system should be improved to increase the thermal comfort level in the building. The optimization of the natural cooling system avoids using the Air Conditioner and the fan, which reduces energy consumption. The attempt to optimize the natural cooling system should also consider the building orientation, position, size of the opening, and overhang position [24]. The vegetation also holds an important role in the cooling system. It is suggested to plant the vegetation among the buildings without hinder the air circulation [6].

Furthermore, there is a green open space on the site. It creates a better microclimate, reduces the air temperature, and decreases the pollution level. Even though the existing green open space needs to be better organized by planting suitable vegetation, so that contribute to the improvement of air quality optimally. In the urban setting, the vegetation should be chosen by considering the morphology, the esthetic, the Oxygen level produced, and durability, the filtering ability, the water-absorbing ability, and maintenance [25]. The proper vegetation selection supports the optimum function of the green open space.

Another promising potency is waste management. Currently, Darul Ulum Islamic Boarding School has implemented simple plastic waste separation. Unfortunately, it does not reuse in daily activities. According to the Ecological Sustainable Development Principles, there is a need to reuse and recycle the waste from the building to fulfill some of the user need. The management of the Islamic Boarding School should encourage the user of the building, especially the student, to use recycled material by issuing the instruction. By applying the $3 \mathrm{R}$ concept, there will be a significant reduction in the waste products of the building.

\section{CONCLUSION}

Based on the explanation above, the research object is not categorized as an Eco-Pesantren. However, it can develop some potencies to implement this concept. The improvement in some aspects of Darul Ulum Islamic School will provide the foundation for the implementation of Eco-Pesantren. It involves many actors such as the architect, the developer, the management, the teachers, the students, the parents, and the government to achieve holistic implementation.

Furthermore, it can be seen that the architect holds an essential role in ecological building implementation. The architect decides what kind of building to produce. The architect's design decision determines the level of energy consumption in the building. A good building performance will contribute to environmental quality improvement, while a bad one is an opposite. Therefore, the architect has to start applying a green triad paradigm (economic-social-ecological values) rather than a black triad paradigm (spacepolicy-business) [16]. It is not only for the environment, but the existence of the building should spread benefits to the surroundings, including humans (social and culture), animals, and vegetation (habitat and ecosystem).

People also have to start applying the religious approach to achieve the success of Eco-Building implementation. As stated in Islam, Muslims have to understand the consequence of being the Caliph that it requires our commitment to provide equilibrium in the universe. One of the actions is applying an Eco-Building concept in any architectural product, particularly in Islamic architectural products. We have shown our responsibility as Muslims towards preserving the environment and maintaining the living creature's prosperity. As this research focuses on the physical aspects of Eco-Pesantren, further research might focus on the role of the inhabitant in Eco-Pesantren implementation. It is mainly related to the green paradigm, which reflects green behavior. Another further research could also assess other Islamic Boarding schools in Banda Aceh (or Aceh) to determine the potency of each study case related to Eco-Pesantren practice.

\section{ACKNOWLEDGMENT}

This research is fully supported by DIPA UIN Ar-Raniry 2019 with contract number 406/PPK-UIN/V/2019.

\section{REFERENCES}

[1] Y. Ardiani, Sustainable Architecture-Arsitektur Berkelanjutan. Jakarta: Erlangga, 2015.

[2] S. Bahri, "Pesantren and the Development of Living Environment: the Study Concept of EcoPesantren in Pondok Pesantren An-Nur HA Rambigundam Jember," International Journal of Management and Administrative Science, vol. 5, no. 10, pp. 43-54, no date.

[3] Herdiansyah, et al, "Environment Awareness to Realizing Green Islamic Boarding School (Eco-Pesantren) in Indonesia," IOP Conf. Ser.: Earth Environ. Sci. 30 012017, 2016.

[4] S. Annur \& B.A. Mappaturi, "Penerapan Prinsip Sustainable Development pada Perancangan Pondok Pesantren Enterpreneur," Journal of Islamic Architecture, vol. 2, no. 2, pp. 82-87, 2012.

[5] R. Safitri \& I. Desiyana, "Investigating the EcoCommunity Concept towards Socio-Spatial Quality in Sector 7 and 9, Bintaro, South Jakarta," Procedia-Social and Behavioral Sciences 179, pp. 183-194, 2015. 
[6] H. Frick \& B.F.X. Suskiyanto, Dasar-Dasar Arsitektur Ekologis. Yogyakarta: Kanisius dan Bandung: ITB, 2007.

[7] J. La Fua, "Eco-Pesantren: Model Pendidikan Berbasis Pelestarian Lingkungan," Jurnal AlTa'dib, vol. 6, no. 1, pp. 113-125, 2013.

[8] J. La Fua, et al, "Islamic Education on Formation of Environment Awareness in Pondok Pesantren Indonesia," IOP Conf. Ser.: Earth Environ. Sci. 156 012035, 2018.

[9] Aulia Fikriarini Muchlis, Dewi Larasati and Sugeng Triyadi S, "Sustainable Development and Architecture: A Conceptual Based on Religious Perspectives," International Journal of Advanced Research in Engineering and Technology (IJARET), vol. 11, no. 4, pp. 1-6, 2020.

[10] W. Lijun \& L. Yan, "Environmental Design and Cultural Spiritual Ecology," Journal of Landscape Research, vol. 34, no. 5, pp. 29-30, 2013.

[11] H. Salam \& N.L. Nik Ibrahim, "Aspects of Sustainable Architecture: An Islamic Perspective," Alam Cipta, vol. 11, no. 2, pp. 2-11, 2018.

[12] F. Mangunjaya, Ekopesantren, Bagaimana Merancang Pesantren Ramah Lingkungan?, Jakarta: Yayasan Pustaka Obor Indonesia, 2014.

[13] A A Sari, et al, "The evaluation of green performance of Miftahul Huda Islamic boarding school, Malang," IOP Conf. Ser.: Mater. Sci. Eng. $669012057,2019$.

[14] M. Feria \& M. Amado, "Architectural Design: Sustainability in the Decision-Making Process," Buildings 2019, vol. 9, no. 135, pp. 1-13, 2019.
[15] W.I. Erfianto, Selamatkan Bumi Melalui Konstruksi Hijau, Perencanaan, Pengadaan, Konstruksi dan Operasi. Yogyakarta: Andi Offset, 2015.

[16] W. Bonenberg \& O. Kapliński, "The architect and the paradigms of sustainable develop ment: a review of dilemmas," Sustainability 2018, vol. 10, no. 100, pp. 1-15, 2018.

[17] L. Groat \& D. Wang, Architectural Research Methods - Second Edition, New Jersey: John Wiley \& Sons, Inc, 2013.

[18] L. Neuman, Metodologi Penelitian Sosial: Pendekatan Kualitatif dan Kuantitatif Edisi 7. Jakarta: PT. Indeks, 2016.

[19] E. Suriani, "Bambu sebagai Alternatif Penerapan Material Ekologis: Potensi dan Tantangannya," EMARA-Indonesia Journal of Architecture, vol. 3, no. 1, pp. 33-42, 2017.

[20] Purwoto,et al, " Efisiensi Penggunaan Panel Surya sebagai Sumber Energi Alternatif," Jurnal Emitor, vol. 18, no. 01, pp. 10-14, 2018.

[21] M. Abrori et al, "Pemanfaatan Solar Cell sebagai Sumber Energi Alternatif di Pondok Pesantren Menuju Pondok Pesantren Mandiri Energi," Jurnal Bakti Saintek: Jurnal Pengabdian Masyarakat Bidang Sains dan Teknologi, vol. 1, no. 1, pp. 17-26, 2017.

[22] S.D. Mintorogo, "Strategi Aplikasi Sel Surya pada Perumahan dan Bangunan Komersial," DIMENSI TEKNIK ARSITEKTUR, vol. 28, no. 2, pp. 129-141, 2000

[23] Juliana et al, "Rainwater Harvesting System System Implementation for Domestic Water Use: the Environment and Financial Benefits," Proceedings of the $2^{\text {nd }}$ International Conference on Sustainable Innovation," pp. 411-421, 2014.

[24] Mn. Hakim, "Pengudaraan Silang pada Pengembangan Rumah Sederhana," NALARs, vol. 8, no. 1, pp. 1-19, 2009.

[25] Kementrian Dalam Negeri, "Instruksi Menteri dalam Negeri tentang Penataan Ruang Terbuka Hijau di wilayah Perkotaan," 1988. 